\title{
Do Pasture-Scale Nutritional Patterns Affect Cattle Distribution on Rangelands?
}

\author{
Dave Ganskopp ${ }^{1}$ and Dave Bohnert ${ }^{2}$ \\ Authors are ${ }^{1}$ Rangeland Scientist, US Department of Agriculture-Agricultural Research Service, \\ Eastern Oregon Agricultural Research Center, 67826-A Highway 205, Burns, OR 97720; and ${ }^{2}$ Range Animal Nutritionist, \\ Oregon State University, Eastern Oregon Agricultural Research Center, 67826-A Hwy 205, Burns, OR 97720.
}

\begin{abstract}
Heterogeneous distribution of ungulates about the landscape can be a particularly vexing problem for resource managers. Although livestock preferences for leaves over stems among plants and patches of herbage are well documented, effects of senescent forage (herbage supporting both green and cured materials) on cattle distribution and nutrition at pasture scales have not been investigated. Our primary objective was to determine the proportions of time cattle spent foraging within senescent and conditioned sectors (areas supporting only current season's herbage) of pastures. Other endeavors included the following: comparing velocities of foraging cattle in conditioned and senescent sectors, determining diet quality of cattle confined to conditioned and senescent treatments, and quantifying levels of forage utilization by cattle in conditioned and senescent treatments. Global positioning system collars were used to track cattle movement and activity in treated crested wheatgrass (Agropyron desertorum [Fisher ex Link] Schultes) pastures. Over a 7-day trial, cattle were found in senescent and conditioned areas $41 \%$ and $59 \%$ of the time, respectively. When cattle were grazing, 32\% of observations were in senescent sectors and $68 \%$ were in conditioned areas. With a decline in standing crop in the conditioned treatment, cattle switched to senescent herbage ( $73 \%$ of observations) on day 7 . Standing crop was reduced by $13 \%$ to $40 \%$ in conditioned sectors and increased by $10 \%$ in senescent areas. Despite disparities in the crude protein of standing crops in senescent $(\overline{\mathrm{x}}=6.5 \%)$ and conditioned $(\overline{\mathrm{x}}=11.3 \%)$ treatments, cattle confined to treatment harvested diets of similar quality $(\overline{\mathrm{x}}=13.6 \% \mathrm{CP})$ at turn-out. Cattle walked farther when making transitions between treatments, and walked farther each day as the trial progressed. A preference of foraging cattle for portions of pastures grazed (conditioned areas) during the previous growing season suggests that utilization patterns established by livestock are self-sustaining.
\end{abstract}

\section{Resumen}

La distribución heterogénea de los ungulados con respecto al paisaje puede ser un problema particularmente irritante para los manejadores de recursos. Mientras que las preferencias del ganado por las hojas sobre los tallos, entre plantas y parches de vegetación están bien documentados, los efectos del forraje senescente (forraje sosteniendo tanto forraje verde como seco) sobre la distribución y nutrición del ganado a nivel de potrero no han sido investigados. Nuestro principal objetivo fue determinar las proporciones de tiempo que el ganado pasa pastando dentro de sectores senescentes y condicionados (áreas que sostienen solo el forraje de la estación en curso) de los potreros. Otras actividades incluidas fueron: comparar las velocidades de pasteo del ganado en los sectores senescentes y condicionados; determinar de la calidad de la dieta del ganado confinado a tratamientos senescente y condicionado y cuantificar los niveles de utilización por el ganado en los tratamientos senescente y condicionado. Estas actividades se lograron con el uso de collares con transmisores de GPS para rastrear los movimientos y actividades del ganado en potreros tratados de "Crestad wheatgrass" (Agropyron desertorum [Fisher ex Link] Schultes). En un periodo experimental de 7 días, el ganado se mantuvo el 41 y $59 \%$ del tiempo en las áreas senescentes y condicionadas respectivamente. Cuando el ganado estaba apacentando, el $32 \%$ de las observaciones se registraron en los sectores senescentes y el $68 \%$ en las áreas condicionadas. Cuando se presentó una disminución de la biomasa en pie de las áreas condicionadas, el ganado cambio al forraje senescente en el séptimo día (73\% de las observaciones). La biomasa en pie se redujo entre 13 a $40 \%$ en los sectores condicionados y se incrementó en $10 \%$ en las áreas senescentes. A pesar de las disparidades de la proteína cruda de la biomasa aérea, entre los tratamientos de senescente $(\overline{\mathrm{x}}=6.5 \%)$ y condicionado $(\overline{\mathrm{x}}=11.3 \%)$ el ganado confinado a tratamiento de dietas de forraje cosechado de calidad similar $(\overline{\mathrm{x}}=13.6 \% \mathrm{CP})$. El ganado caminó más cuando realizó transiciones entre tratamientos y conforme el experimento avanzó camino más cada día. La preferencia del ganado pastando por porciones del potrero apacentado (áreas condicionadas ) durante la estación de crecimiento previa sugiere que los patrones de utilización establecidos por el ganado son autosostenibles.

Key Words: range management, forage conditioning, diet quality, crested wheatgrass, grazing behavior

Eastern Oregon Agricultural Research Center, including the Burns and Union stations, is jointly operated by the Oregon Agricultural Experiment Station of Oregon State University, Corvallis, OR, and the USDA-Agricultural Research Service.

Mention of product or proprietary names are for information only and do not convey endorsement of one product over another.

Correspondence: David Ganskopp, USDA-ARS, 67826-A Highway 205, Burns, OR 97720. Email: david.ganskopp@oregonstate.edu

Manuscript received 15 November 2004; manuscript accepted 3 December 2005.

\section{INTRODUCTION}

Heterogeneous distribution patterns of various ungulates about the landscape have long interested ecologists, and are, at times, a particularly vexing problem for resource managers. Several researchers have documented preferential use by wild and domestic herbivores of conditioned plants or patches of herbage 
where older senescent material was removed by grazing or fire (Willms et al. 1980; Gordon 1988; Ruyle and Rice 1991; Ganskopp et al. 1992; Pfeiffer and Hartnett 1995). Ganskopp et al. (1993) found cattle cognizant of even a single cured seed stalk within green tussocks of crested wheatgrass (Agropyron desertorum [Fisher ex Link] Schultes). In that study, 35\% less material was harvested by beef cattle from plants with reproductive tillers than from similar tussocks without reproductive tillers. When some caespitose grasses go ungrazed in a given year, intact senescent stems may persist, and livestock are less likely to graze those plants during subsequent years. Economically significant amounts of forage may be lost if tussocks supporting both green and senescent herbage begin to characterize pastures (Romo et al. 1997).

Although livestock preferences for leaves over stems within individual plants and plant patches are well documented (Murray 1984; Norton and Johnson 1986; Ruyle and Rice 1991), the effect of mixed green and senescent herbage on beef cattle distribution at larger scales has not been studied. The central hypotheses tested were that cattle would more frequently occupy and spend more time foraging in conditioned than in senescent portions of pastures. Other objectives included the following: comparing velocities of foraging cattle in conditioned and senescent sectors, quantifying the duration of bouts or series of observations within treatments, determining diet quality of cattle confined to senescent and conditioned sectors of pastures at turn-out, and quantifying levels of forage utilization by cattle accessing senescent and conditioned treatments.

\section{MATERIALS AND METHODS}

\section{Study Area}

The study was conducted on the Northern Great Basin Experimental Range approximately $72 \mathrm{~km}$ west-southwest of Burns, Oregon (lat 432 $8^{\prime} 30.77^{\prime \prime} \mathrm{N}$, long $119^{\circ} 40^{\prime} 29.77^{\prime \prime} \mathrm{W}, \mathrm{WGS}-1984$; 1386 m elevation). Mean annual precipitation $(n=67,1937-$ 2004 ) is $282 \mathrm{~mm}$ with peak monthly accumulations in November, December, January, and May (range 29-36 mm). Mean temperature is $7^{\circ} \mathrm{C}$ with extremes of $-31^{\circ} \mathrm{C}$ and $42^{\circ} \mathrm{C}$ (referenced as Squaw Butte Experiment Station in NOAA 2004 records).

\section{Pastures and Forage Conditioning}

Four pastures, ranging from 13 to 14 ha, were selected for study. Slope averaged less than $1 \%$, and soils were a complex of loamy materials (Ratto-Gradon Variant-Anawalt complex, Gradon Variant gravelly loam, Vil-Decantel Variant-Ratto complex, and Milican fine sandy loam [Lentz and Simonson 1986]). Existing vegetation included a shrub layer dominated by Wyoming big sagebrush (Artemisia tridentata subsp. wyomingensis Beetle) and an understory of crested wheatgrass established in 1953.

In mid-July 2000, near the end of the growing season, 4 pastures were temporarily halved using electric fence. By coin toss, one half of each pasture was designated a "senescent" treatment and the second half a "conditioned" treatment. Over 7 days, about 75 cow-calf pairs grazed the conditioned sector of each pasture to a $2.5-\mathrm{cm}$ stubble. Cattle and electric fences were subsequently removed, and pastures not grazed by livestock until late May 2001.
Water was available from a centrally located tank on the north or south boundary of each pasture. In each instance, treatment boundaries bisected tanks to ensure watering activities did not bias cattle distribution toward either treatment.

Precipitation contributing to the year 2000 standing crop (September 1999-June 2000) was $242 \mathrm{~mm}$ or $94 \%$ of the long term (1937-2004) mean. Precipitation supporting herbage growth through late May 2001, when treated pastures were stocked, totaled $136 \mathrm{~mm}$ or $59 \%$ of average. That being the case, standing crop for the 2001 growing season was somewhat depressed.

\section{Diet Quality}

During 21 and 22 May 2001, 6 ruminally cannulated Hereford $\times$ Angus steers (mean body weight $=359 \pm 4.7 \mathrm{~kg} \mathrm{SE}$ ) were used to sample diet quality of cattle confined to senescent and conditioned treatments. Before sampling, steers were held in a nearby crested wheatgrass pasture for 4 days to provide a pretrial forage acclimation period. Herbage in the senescent treatment was a mixture of cured reproductive and vegetative culms from the 2000 growing season, and green herbage from the 2001 growing season. All herbage in the conditioned treatment was a product of the 2001 growing season. Current season growth was in the early-boot phenological stage for both treatments.

The 6 steers were randomly assigned to 2 groups of 3 with each group assigned a pasture. Steers were ruminally evacuated following Lesperance et al. (1960) with one exception, that after evacuation, the rumen wall was rinsed with water and wiped with a wet sponge. One group first grazed the conditioned treatment in their pasture while their companions began in the senescent sector of a second pasture. Assistants were stationed at midpasture to keep steers from leaving the designated treatment. After 30-minute grazing periods, steers were captured, and ruminal masticate was removed and placed in labeled plastic bags; the samples were stored on ice. Groups were released to forage for another 30 minutes on the opposing treatment and recaptured; the masticate was removed and stored, and the initial rumen contents replaced. This process was repeated the subsequent morning in the remaining 2 pastures with each group beginning on an opposing treatment from that first grazed the previous day.

After leaving the field, masticate samples were frozen $\left(-20^{\circ} \mathrm{C}\right)$, lyophilized, ground with a Model 4 Thomas Wiley Laboratory mill through a 1-mm mesh, and subsequently analyzed for crude protein (percent nitrogen $\times 6.25[\mathrm{CN}$ 2000, LECO Corp, St. Joseph, MI]), neutral detergent fiber (NDF) (Robertson and Van Soest 1981), and acid detergent fiber (ADF) (Goering and Van Soest 1970) using procedures modified for a Ankom 200 Fiber Analyzer, and in situ dry matter digestibility (ISDMD) (Damiran et al. 2002) using 0.5-g samples and steers maintained on meadow foxtail (Alopecurus pratensis L.) hay.

\section{Standing Crop and Forage Quality}

On 24 May 2001, standing crop was sampled to a $2.5-\mathrm{cm}$ stubble from $201-\mathrm{m}^{2}$ plots at paced intervals across both diagonals of each pasture/treatment combination. Two samples from each group of 20 were selected at random, sorted into 
live/dead components, and the materials returned to labeled paper bags. All herbage was oven dried at $55^{\circ} \mathrm{C}$ for 48 hours then weighed with an analytic balance to quantify standing crop. After weighing, the 2 live/dead samples from each treatment sector and 2 additional standing crop samples were extracted and pooled by component to ensure adequate quantities for subsequent forage quality analyses. Samples were ground to pass a $1-\mathrm{mm}$ mesh and stored in labeled plastic bags for later assessment of ADF, NDF, CP, and ISDMD. Standing crop was sampled a second time, immediately after our grazing trials, to quantify levels of forage utilization.

\section{Cattle Stocking and Global Positioning System (GPS) Collar Configuration}

At midmorning on 29 May 2001, 20 nonlactating Hereford $\times$ Angus cows $(\mathrm{BW}=459 \pm 6.4 \mathrm{~kg} \mathrm{SE})$ were randomly assigned to the 4 pastures. Three of 5 cattle in each pasture wore Lotek 2200 GPS collars that had been fitted 4 days previously. The collars acquired and stored cattle positions at 10-minute intervals beginning at noon (Pacific daylight time) on 29 May and ending at noon on 6 June.

Motion sensors in each of the GPS collars were useful for monitoring the left/right and acceleration/deceleration movements of the animal's head. These data may be used to classify and estimate durations of animal activities like grazing, resting, and traveling (Ungar et al. 2005). Motion-sensor counters were programmed to tally over 3-minute intervals within each 10 minute position integration. Data accrued between minutes 9 and 10 were deleted when the GPS unit switched on to acquire GPS coordinates.

GPS Data. After cattle had occupied pastures for 1 week, GPS collars were removed, data were downloaded, and differential corrections were applied to coordinates using LotekN4 V1.1895 software. Base-station files were acquired from a US Forest Service-Bureau of Land Management station near Hines, Oregon (USDA Forest Service 2006), about $47 \mathrm{~km}$ east of our study site. To facilitate algebraic derivation of distances between successive coordinates, corrected data were transformed from latitude/longitude to Universal Transverse Mercator form (UTM $11 \mathrm{~N}$, WGS-84) using Trimble's GPS Pathfinder Office V2.9 software.

Custom software, programmed in Microsoft QBasic, processed the corrected and transformed data for the following purposes: 1) to measure the distance between successive coordinates, 2) to establish whether a coordinate was part of a series of observations within a treatment or a transition to the alternative, and 3) to examine the associated motion sensor data and label each coordinate as being committed to either "active" or "other" activities. We labeled GPS "active" coordinates as grazing locations when associated left/right motion sensor counts exceeded the 55 th percentile for each individual cow.

\section{Response Variables, Experimental Design, and Statistical Analyses}

Given the sequential nature of GPS output and a consistent integration interval (10 minutes), several response variables may be derived from collar data. The number of observations occurring in each of the 2 treatments and those involving transitions between treatments were tallied for each cow each day across all cattle activities ( $\mathrm{sum}=144 \mathrm{day}^{-1} \cdot \mathrm{cow}^{-1}$ ) and again for each cow for coordinates associated with grazing endeavors (average sum $=66.3 \pm 0.78 \mathrm{day}^{-1} \cdot \mathrm{cow}^{-1} \mathrm{SE}$, $n=84)$. Statistical analyses were conducted on frequency data, and values subsequently converted to units of time $\left(\mathrm{h} \cdot \mathrm{d}^{-1}\right)$ for presentation purposes.

Travel distance between successive coordinates for each cow was derived from data describing all activities within treatments and for transitions between treatments. Distance between successive coordinates was also derived for periods when cattle were grazing and tallied within treatments and for transitions between treatments. Distance measures were analyzed at 2 scales. For the first, values were converted to velocities $\left(\mathrm{m} \cdot \mathrm{min}^{-1}\right)$ to explore the null hypothesis that cattle moved at equivalent rates within treatments and when moving between treatments. For the second, distance measures were summed for all activities and for movements associated with grazing across the entire day. The difference between the "all activity" sum and "grazing activity" sum was labeled "other activities." The "other activity" total was most likely a product of minor travels while cattle were resting, trailing to or from water or mineral supplements or other areas of the pasture, or lastly, inherent GPS error. Mean error, calculated for a stationary GPS collar over 100 integrations was $4.5 \pm 0.4 \mathrm{~m}$ (file data). Readers should note that distance and velocity measures are most certainly underestimated, because straight line travel was assumed between successive GPS coordinates.

Forage quality analyses included assays of standing herbage from the senescent sectors, sorted cured and green herbage from the senescent sectors, and standing crop samples from the conditioned treatment. Herbage from the conditioned treatment did not contain sufficient cured material to warrant separate chemical analyses.

Field layout of the project was a randomized complete block with 4 blocks, 2 treatments (conditioned and senescent sectors), and a 7-day duration. A treated portion of a pasture or block was the experimental unit. The mean of 3 subsamples $(3 \mathrm{col}-$ lared cows) within each block served as a single observation in frequency, distance, and diet quality analyses. Frequency, velocity, and distance measures of cattle for treatments and days were analyzed with a repeated measures analysis of variance with days as the repeated factor. Degree of freedom determinations followed Kenward and Roger (1997).

For analyses of single effect variables (standing crop, forage and diet quality, total distance traveled per day, and counts of grazing bouts within treatments) treatment effects were tested with a randomized complete block analysis of variance with the block $\times$ treatment interaction functioning as the error term. Statistical significance in all analyses was assumed at $P<0.05$, and mean separations were accomplished using Fisher's Protected LSD procedures. Throughout text and tables, values following “ \pm ” symbols are standard errors of the mean.

\section{RESULTS}

\section{Standing Crop, Diet Quality, and Forage Utilization}

When the trial began, mean standing crop was $543 \pm 6.6$ and $202 \pm 39 \mathrm{~kg} \cdot \mathrm{ha}^{-1}$ in senescent and conditioned treatments, respectively. About $50 \%$ of the senescent standing crop was 
Table 1. Forage quality indices of herbage components and steer diets from conditioned and senescent sectors of crested wheatgrass pastures on the Northern Great Basin Experimental Range, near Burns, Oregon, in late May 2001. Bold treatment means within a row and beneath a common forage quality index are significantly different $(P<0.05)$.

Forage quality indices

\begin{tabular}{|c|c|c|c|c|c|c|c|c|}
\hline \multirow[b]{2}{*}{ Forage component } & \multicolumn{2}{|c|}{ Crude protein } & \multicolumn{2}{|c|}{ Neutral detergent fiber } & \multicolumn{2}{|c|}{ Acid detergent fiber } & \multicolumn{2}{|c|}{ Digestibility (ISDMD) } \\
\hline & Senescent & Conditioned & Senescent & Conditioned & Senescent & Conditioned & Senescent & Conditioned \\
\hline Standing crop & $6.5 \pm 0.2$ & $11.3 \pm 0.3$ & $66 \pm 1.5$ & $60 \pm 0.6$ & $38 \pm 1.2$ & $30 \pm 0.3$ & $47 \pm 1.8$ & $58 \pm 0.6$ \\
\hline Senescent herbage & $1.9 \pm 0.2$ & - & $74 \pm 1.0$ & - & $47 \pm 0.9$ & - & $39 \pm 0.5$ & - \\
\hline Live herbage & $11.1 \pm 0.2$ & $11.3 \pm 0.2$ & $61 \pm 1.0$ & $61 \pm 0.8$ & $30 \pm 0.3$ & $29 \pm 0.4$ & $56 \pm 0.6$ & $58 \pm 0.6$ \\
\hline Steer diets & $13.1 \pm 0.7$ & $14.1 \pm 0.4$ & $62 \pm 2.6$ & $58 \pm 1.4$ & $29 \pm 1.1$ & $27 \pm 0.6$ & $57 \pm 1.9$ & $61 \pm 1.2$ \\
\hline
\end{tabular}

cured material, whereas only traces of senescent forage occurred in the conditioned herbage. Chemical analyses of standing crop revealed more $(P<0.01)$ crude protein and in situ dry matter digestibility in the conditioned than in senescent treatment (Table 1). Higher NDF and ADF concentrations occurred with senescent standing crop than with the conditioned treatment $(P<0.01)$. Forage quality measures of live herbage (Table 1) were similar between treatments and diet quality of steers confined to treatment were also similar as indexed by measures of $\mathrm{CP}(\overline{\mathrm{x}}=13.6 \pm 0.6)$, NDF $(\overline{\mathrm{x}}=59.9 \pm 2.1), \quad \mathrm{ADF} \quad(\overline{\mathrm{x}}=28.4 \pm 1.0), \quad$ and $\quad$ ISDMD $(\overline{\mathrm{x}}=59.5 \pm 1.9)$.

When grazing was terminated, standing crop in the senescent treatment had increased from an initial $543 \pm 7$ to $596 \pm 24 \mathrm{~kg} \cdot \mathrm{ha}^{-1}$, almost a $10 \%$ growth increment. A measured decrease from $202 \pm 38$ to $175 \pm 23 \mathrm{~kg} \cdot \mathrm{ha}^{-1}$ in the conditioned treatment suggested we achieved a rather light forage utilization level of $13 \%$. Because herbage was still growing during our grazing trials, however, an accurate assessment of forage utilization becomes a complex issue. If we assume conditioned sectors acquired the same growth increment of $53 \mathrm{~kg} \cdot \mathrm{ha}^{-1}$ as the senescent treatment, then potentially $80 \mathrm{~kg} \cdot \mathrm{ha}^{-1}$ of herbage was removed by cattle from the condi-

Table 2. Hours $\cdot$ day $^{-1}$ cattle were detected transitioning between or within senescent or conditioned treatments of crested wheatgrass pastures by GPS collars for all activities and coordinates associated with grazing activities on the Northern Great Basin Experimental Range. Positions were sampled at 10-minute intervals over 7 days in late May 2001 near Burns, Oregon. Paired bold font senescent/conditioned means within a day and activity are significantly different $(P<0.05)$.

\begin{tabular}{|c|c|c|c|c|c|c|}
\hline \multirow[b]{2}{*}{ Day } & \multicolumn{3}{|c|}{ All activities } & \multicolumn{3}{|c|}{ Grazing } \\
\hline & Transitions & Senescent & Conditioned & Transitions & Senescent & Conditioned \\
\hline & & & h & & & -- \\
\hline 1 & $1.4 \pm 0.4$ & $2.9 \pm 0.6$ & $19.6 \pm 0.5$ & $1.2 \pm 0.3$ & $0.8 \pm 0.2$ & $8.5 \pm 0.2$ \\
\hline 2 & $1.1 \pm 0.2$ & $3.0 \pm 0.9$ & $19.9 \pm 1.2$ & $0.9 \pm 0.1$ & $2.0 \pm 0.5$ & $7.2 \pm 0.3$ \\
\hline 3 & $1.9 \pm 0.2$ & $8.7 \pm 2.4$ & $13.4 \pm 2.5$ & $1.2 \pm 0.1$ & $2.5 \pm 0.3$ & $6.8 \pm 0.4$ \\
\hline 4 & $1.2 \pm 0.1$ & $7.2 \pm 1.4$ & $15.5 \pm 1.3$ & $0.9 \pm 0.0$ & $1.8 \pm 0.6$ & $9.4 \pm 0.2$ \\
\hline 5 & $1.2 \pm 0.2$ & $11.9 \pm 1.2$ & $10.8 \pm 1.3$ & $1.0 \pm 1.0$ & $3.5 \pm 0.7$ & $7.1 \pm 0.9$ \\
\hline 6 & $1.1 \pm 0.2$ & $10.5 \pm 2.1$ & $12.4 \pm 2.2$ & $1.0 \pm 0.1$ & $3.5 \pm 0.8$ & $7.1 \pm 0.7$ \\
\hline 7 & $1.2 \pm 0.2$ & $19.5 \pm 0.6$ & $3.3 \pm 0.6$ & $1.0 \pm 0.1$ & $7.1 \pm 0.5$ & $2.7 \pm 0.7$ \\
\hline Mean & $1.3 \pm 0.1$ & $9.1 \pm 1.1$ & $13.6 \pm 1.1$ & $1.1 \pm 0.1$ & $3.0 \pm 0.8$ & $7.0 \pm 0.8$ \\
\hline
\end{tabular}

tioned treatment, and a forage utilization estimate of $40 \%$ may be more appropriate.

\section{GPS Collar Performance}

All 12 GPS collars acquired their scheduled complement of integrations ( $n=1008$ ) yielding a total of 12096 coordinates. Of that total, 14 coordinates were indeterminate during differential correction. Indeterminate points are typically a product of roving and base station GPS units viewing slightly different satellite arrays. Previous checks of accuracy with stationary GPS collars revealed a mean distance between corrected and uncorrected coordinates of $4.1 \pm 0.39 \mathrm{~m}(n=100)$. That being the case, uncorrected coordinates were substituted for the 14 missing corrected values.

\section{Frequency Cattle Were Detected Within Treatments}

Collared cattle were detected in the senescent treatments 4919 $(40.6 \%)$ times, and 7177 (59.3\%) observations occurred in conditioned areas. A total of 757 transitions between treatments were noted. On a daily basis, for $1 \mathrm{cow}$, this reduced to about 9 transitions between treatment zones. After transitions were discounted from the total number of observations, 4541 $(40 \%)$ coordinates occurred in the senescent treatment and $6798(60 \%)$ in the conditioned treatment. Analysis of variance describing all activities revealed significant treatment $(P<0.02)$ and treatment $\times$ day $(P<0.01)$ effects (Table 2$)$. During the first 4 days of the trial, cattle exhibited about a 3:1 $(P<0.05)$ preference for the conditioned treatment. On days 5 and 6, cattle were detected within the 2 treatments for about equal durations. On day 7 , cattle exhibited a reversal, and more $(P<0.05)$ time was spent in the senescent $(\overline{\mathrm{s}}=19.5 \pm 0.6 \mathrm{~h})$ than in conditioned treatments $(\overline{\mathrm{x}}=3.3 \pm 0.6 \mathrm{~h})$.

The 55th percentile left/right motion sensor threshold for assigning associated coordinates to grazing activities varied substantially among cows. We suspect a large proportion of that variability was related to differences in collar fit. With a snug fit, motion sensors most likely register very subtle movements. Collars display pendulum-like motions with a loose fit on thinner cows, and sensors register fewer movements. The mean motion sensor threshold for assigning a coordinate to a grazing activity was $86.5 \pm 14.4$ and ranged from 16 , for the lightest cow (410 $\mathrm{kg})$ to 166 for the heaviest $(489 \mathrm{~kg})$. Despite this range of variability, our selection criteria resulted in approximately $66.3 \pm 1.1$ observations or $11.1 \pm 0.2 \mathrm{~h} \cdot \mathrm{day}^{-1} \cdot \mathrm{cow}^{-1}$ flagged 


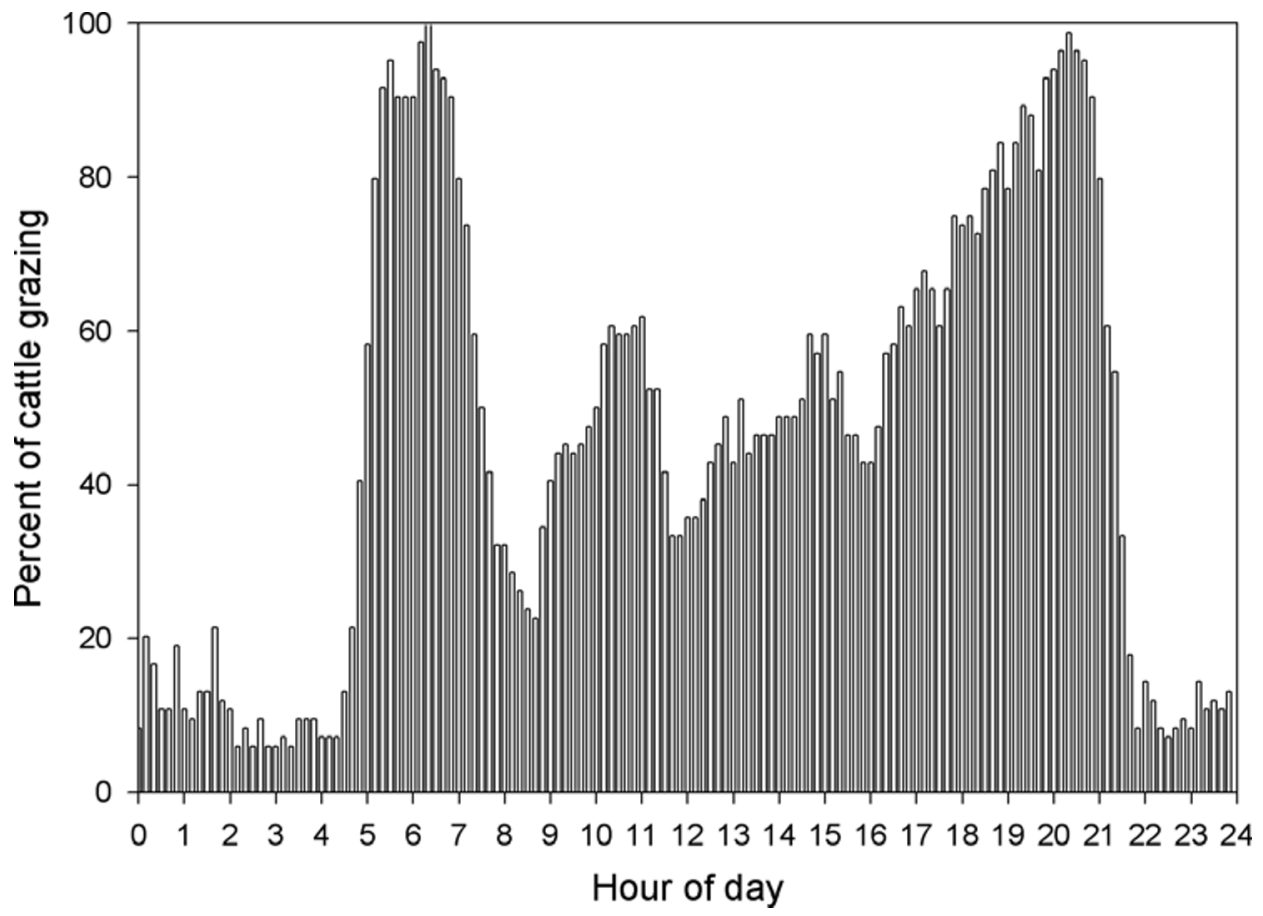

Figure 1. The diurnal pattern of percentage of 12 cattle classified as active and most likely grazing by GPS collar motion sensors integrating at 10-minute intervals $\left(n=144 \mathrm{~d}^{-1}\right)$ and averaged over 7 days while cattle occupied pastures supporting senescent and conditioned sectors of crested wheatgrass in late May 2001 on the Northern Great Basin Experimental Range near Burns, Oregon.

as active or grazing observations. About $43 \%$ of the estimated grazing activity occurred during the first half of the day and $57 \%$ occurred during PM hours (Fig. 1).

Analyses of coordinates associated with grazing activities also exhibited significant treatment $(P=0.02)$ and treatment $\times$ day effects $(P<0.01)$. Through the first 6 days, cattle favored the conditioned over senescent treatment by about a 2.9:1 ratio (Table 2). The treatment $\times$ day interaction occurred on day 7 when cattle shifted about $66 \%$ or 7.1 hours of their daily foraging time to the senescent treatment. Duration of grazing bouts, or successive observations within treatments while grazing, averaged $54 \pm 3$ minutes in the conditioned treatment and $33 \pm 2$ minutes in the senescent treatment $(P=0.01)$.

For periods when cattle were not grazing but were involved in other activities (resting, ruminating, walking), about $6.1 \mathrm{~h} \cdot$ day $^{-1}$ were spent in senescent treatments and 6.6 $\mathrm{h} \cdot \mathrm{day}^{-1}$ in conditioned areas across the trial. Analyses revealed a treatment $\times$ day interaction $(P<0.01)$ but no significant $(P>0.45)$ main effects (data not shown but may be derived by difference from Table 2). For days 1 and 2, cattle averaged about $11.9 \mathrm{~h} \cdot \mathrm{day}^{-1}$ in the conditioned treatments and $1.6 \mathrm{~h} \cdot \mathrm{day}^{-1}$ in senescent treatments. They averaged about $6 \mathrm{~h} \cdot \mathrm{day}^{-1}$ in each treatment on days $3,4,5$, and 6 , but on day 7 , nearly all nongrazing observations (12.4 out of a total of $13.2 \mathrm{~h}$ ) occurred within the senescent treatment.

\section{Velocity and Total Distance Traveled Each Day}

Again, we remind readers that distance and velocity measures are typically underestimated by our techniques, because straight-line travel is assumed between successive coordinates.
During the trial, cattle traveled about $4.4 \mathrm{~km} \cdot \mathrm{day}^{-1}$. Mean velocity between successive cattle positions throughout the study was $3.028 \pm 0.3 \mathrm{~m} \cdot \mathrm{min}^{-1}$. In analyses of the full data set (all activities), velocity between successive coordinates within treatments and during transitions between treatments exhibited significant $(P<0.01)$ treatment, day, and treatment $\times$ day effects (Table 3). With a couple of exceptions (days 2 and 3), cattle traveled more rapidly when making transitions between treatments than when moving within senescent or conditioned sectors (Table 3). Among daily velocity comparisons between the senescent and conditioned treatments, there were 2 days (4 and 7) where velocities were lower in the senescent treatment than in the conditioned. Between-treatment comparisons were similar for the other 5 days of the trial.

In the analyses of travels associated with grazing activities, we found significant treatment and day effects $(P<0.02)$. When cattle transitioned between treatments, velocity was greater than for movements within the senescent or conditioned treatments (Table 3). With a couple of exceptions, grazing cattle traveled at progressively greater velocity each succeeding day (Table 3 ).

Total distance traversed each day averaged $4359 \mathrm{~m}$ (Table 4). Also, cattle tended to increase their total travels each day as the trial progressed. When partitioned between grazing and other activities, about $92 \%$ of a cow's daily travels were associated with grazing endeavors.

\section{DISCUSSION}

Cattle in this study clearly preferred conditioned portions of pastures that were grazed during the previous year's growing season. Cattle exhibited about a 3-to-2 conditioned vs. senescent 
Table 3. Mean velocity for cattle across all activities and for grazing cattle held in pastures supporting senescent and conditioned sectors of crested wheatgrass on the Northern Great Basin Experimental Range over 7 days in late May 2001 near Burns, Oregon. Included are travels confined to senescent and conditioned sectors of pastures and instances when cattle transitioned between treatments. Under the all activities heading, means within a row sharing a common letter are not significantly different $(P>0.05)$. Under grazing activities, day effect means within a column sharing a common letter are not significantly different $(P>0.05)$.

\begin{tabular}{|c|c|c|c|c|c|c|c|}
\hline \multirow[b]{2}{*}{ Day } & \multicolumn{3}{|c|}{ All activities } & \multicolumn{4}{|c|}{ Grazing activities only } \\
\hline & Transitions & Senescent & Conditioned & Day effects & Transitions & Senescent & Conditioned \\
\hline & --------------- & - & ------------. & $--m \cdot \min ^{-}$ & 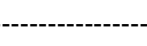 & 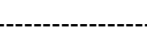 & --- \\
\hline 1 & $4.4 \pm 1.2 \mathrm{a}$ & $1.5 \pm 1.0 b$ & $2.1 \pm 0.9 a$ & $5.5 \pm 0.7 a$ & - & - & - \\
\hline 2 & $4.4 \pm 1.0 \mathrm{a}$ & $4.0 \pm 1.0 \mathrm{ab}$ & $2.1 \pm 0.8 \mathrm{~b}$ & $5.9 \pm 0.4 a$ & - & - & - \\
\hline 3 & $4.8 \pm 0.8 \mathrm{a}$ & $3.2 \pm 0.9 a$ & $3.4 \pm 0.8 a$ & $7.6 \pm 0.7 c$ & - & - & - \\
\hline 4 & $7.8 \pm 1.3 a$ & $1.0 \pm 1.4 b$ & $3.7 \pm 1.3 \mathrm{c}$ & $7.4 \pm 1.1 b c$ & - & - & - \\
\hline 5 & $9.7 \pm 1.8 \mathrm{a}$ & $1.7 \pm 1.9 b$ & $3.7 \pm 1.7 b$ & $7.8 \pm 0.8 \mathrm{c}$ & - & - & - \\
\hline 6 & $6.7 \pm 1.7 a$ & $1.8 \pm 1.8 \mathrm{~b}$ & $3.5 \pm 1.7 b$ & $6.0 \pm 0.5 a b$ & - & - & - \\
\hline 7 & $10.2 \pm 1.8 \mathrm{a}$ & $1.9 \pm 1.9 b$ & $6.3 \pm 1.7 c$ & $7.6 \pm 0.6 c$ & - & - & - \\
\hline Mean & $6.9 \pm 0.9$ & $2.2 \pm 0.4$ & $3.6 \pm 0.5$ & $6.9 \pm 0.4$ & $8.9 \pm 0.8 a$ & $5.9 \pm 0.4 b$ & $5.9 \pm 0.3 b$ \\
\hline
\end{tabular}

ratio over the 7-day trial for all activities and about a 3-to-1 conditioned vs. senescent ratio with coordinates related to grazing endeavors. Concurrently, we experienced a reduction in standing crop on our conditioned treatment and accumulated additional herbage in our senescent treatment. This strongly implies that a grazing distribution pattern established in one year, with its associated effects on the character of the vegetation, will likely be duplicated in a pasture with conservative stocking rates in subsequent years (Bakker et al. 1983; Ring et al. 1985; Willms et al. 1988; Hirata 1998). Foraging bison are attracted to areas in prairie settings for up to 2 years after fire consumes decadent herbage (Vinton and Hartnett 1992), but year-to-year persistence of preference for grazed patches of herbage have not been previously studied in the Great Basin.

Experiments conducted on artificially prepared pasture have suggested animals select areas or patches of plants with higher herbage mass to potentially maximize intake rate (Black and Kenny 1984; Laca et al. 1992; Illius and Gordon 1993; Distel et al. 1995; Illius et al. 1999). That was not the case in this study.

Table 4. Total distance traveled day $^{-1}$ for all activities, total distance traveled day ${ }^{-1}$ while grazing, and total distance traveled day ${ }^{-1}$ by cattle involved in other activities while held for 7 days in pastures supporting senescent and conditioned sectors of crested wheatgrass in late May 2001 on the Northern Great Basin Experimental Range near Burns, Oregon. Means within a column sharing a common letter are not significantly different $(P>0.05)$.

\begin{tabular}{|c|c|c|c|}
\hline Day & All activities & Grazing activities & Other activities \\
\hline & & $-m-$ & \\
\hline 1 & $3622 \pm 535 a$ & $3261 \pm 510 a b$ & $361 \pm 58$ \\
\hline 2 & $3647 \pm 189 a$ & $3190 \pm 179 a$ & $457 \pm 86$ \\
\hline 3 & $4590 \pm 96 b$ & $4202 \pm 108 c$ & $388 \pm 25$ \\
\hline 4 & $4947 \pm 175 b$ & $4580 \pm 168 c$ & $367 \pm 37$ \\
\hline 5 & $4866 \pm 133 b$ & $4561 \pm 174 c$ & $306 \pm 59$ \\
\hline 6 & $4228 \pm 234 a b$ & $3949 \pm 212 b c$ & $279 \pm 24$ \\
\hline 7 & $4612 \pm 78 b$ & $4225 \pm 90 c$ & $388 \pm 46$ \\
\hline Mean & $4359 \pm 128$ & $3995 \pm 130$ & $364 \pm 20$ \\
\hline
\end{tabular}

For the preponderance of the trial (days 1-6), cattle preferred conditioned sectors supporting less than half the standing crop of senescent areas. The previously grazed conditioned sectors in this study supported a nutritionally superior standing crop (Table 1) as indexed by crude protein, fiber, and digestibility measures. Bakker et al. (1983), Illius et al. (1987), Cid and Brizuela (1998), Ogura et al. (2002a), and Garcia et al. (2003) report similar findings with animals favoring quality over quantity. On day 7 of our study, grazing cattle switched from conditioned to senescent sectors. Definitively ascertaining whether this was a response to forage quantity or quality changes (Ogura et al. 2002b) will require additional study with more intensive measures of standing crop and diet quality.

Despite differences in standing crop forage quality between treatments (Table 1), rumen-cannulated steers confined to conditioned or senescent treatments harvested diets that were nutritionally similar as indexed by measures of crude protein, fiber, and digestibility. This reinforces previous observations that cattle can, via selective grazing, effectively acquire a higher quality diet than standing crop samples would imply (Cruz and Ganskopp 1998). Because our diet samples were collected only at the beginning of the trial, we do not know if the nutritional status of cattle was sustained on both treatments as herbage supplies dwindled.

Cattle tended to travel greater distances by increasing velocity as they foraged each day (Tables 3 and 4), suggesting that additional effort compensated for a dwindling supply of forage in our conditioned treatment. Seasonal disparities in the daily travels of foraging cattle have been observed in the past with stock afforded the luxury of travel excesses on high quality herbage and a reduction of grazing distances as forage quality deteriorates (Stuth et al. 1987; Stuth 1991; Ganskopp et al. 1997). Given those observations, we expected reduced velocity when cattle were grazing the lower-quality senescent treatment. That did not occur, however, and velocity of grazing cattle averaged about $6.9 \mathrm{~m} \cdot \mathrm{min}^{-1}$ regardless of treatment occupied.

Obviously, high-quality green forage existed within the generally lower quality, senescent treatment, and via selective grazing, cattle were able to extract a nutritious diet. Because 
the collared cows tended to concentrate their grazing in the conditioned treatment for the first portions of the trial, quality components were likely still available for use the last day of the trial in the senescent treatment. The late-trial shift to the senescent treatment, and progressively increasing travel distances and velocities suggest that cattle were willing to forage more extensively and expend more energy in the senescent areas to obtain high-quality forage. Garcia et al. (2003) found that sheep could sustain diet quality with selective grazing in heavily stocked pastures, but they could not alter grazing times enough to sustain daily intake levels.

\section{MANAGEMENT IMPLICATIONS}

A clear preference of foraging cattle for portions of pastures that were grazed during the previous growing season suggests that utilization patterns established by livestock at pasture scales are self-sustaining. When given a choice, cattle initially seek areas of uncontaminated, high-quality forage, and sacrifice quality for quantity only after more nutritious stands of herbage have been consumed.

On a negative note, livestock distribution issues are some of the most universally vexing problems for managers, and areas conditioned by herbivory may endure the effects of grazing year after year. Simultaneously, other portions of a pasture may contribute little to managers focused on maximizing returns. Although little can be done about the geophysical characteristics (distance to water, degree of slope, surface rock, etc.) affecting cattle distribution in pastures, several tools are available to remove a senescent forage impediment. These include prescribed burns, mowing if the landscape and economics allow, and heavily stocked grazing applications that will be most successful after herbage has cured and cattle forage less selectively. One may also use temporary water tanks or supplement tubs to attract cattle and hold them on habitually unused senescent vegetation. These practices will make more of the pasture acceptable to both wild and domestic grazers in subsequent growing seasons.

\section{LITERATURE CITED}

Bakker, J. P., J. de Leeus, and S. E. Wieren. 1983. Micro-patterns in grassland vegetation created and sustained by sheep-grazing. Vegetatio 55: 153-161.

Black, J. L., and P. A. Kenny. 1984. Factors affecting diet selection by sheep. II. Height and density of pasture. Australian Journal of Agricultural Research 35:551-563.

Cid, M. S., AND M. A. BRizuela. 1988. Heterogeneity in tall fescue pastures created and sustained by cattle grazing. Journal of Range Management 51:644-649.

Cruz, R. and D. Ganskopp. 1998. Seasonal preferences of steers for prominent northern Great Basin grasses. Journal of Range Management 51: 557-565.

Damiran, D., T. Delcurto, D. W. Bohnert, G. D. Pulsipher, and S. L. Findholt. 2002. Comparison of techniques and grinding size to estimate digestibility of forage base ruminant diets. Proceedings of Western Section American Society Animal Science 53:341-344.

Distel, R. A., R. A. Laca, T. C. Griggs, and M. W. Demment. 1995. Patch selection by cattle: maximization of intake rate in horizontally heterogeneous pastures. Applied Animal Behaviour Science 45:11-21.
Ganskopp, D., R. Angell, and J. Rose. 1992. Response of cattle to cured reproductive stems in a caespitose grass. Journal of Range Management 45:401-404.

Ganskopp, D., R. Angell, and J. Rose. 1993. Effect of low densities of senescent stems in crested wheatgrass on plant selection and utilization by beef cattle. Applied Animal Behaviour Science 38:227-233.

Ganskopp, D., B. Myers, S. Lambert, and R. Cruz. 1997. Preferences and behavior of cattle grazing 8 varieties of grasses. Journal of Range Management 50:578-586.

Garcia, F., P. Carrere, J. F. Sousanna, and R. Baumont. 2003. The ability of sheep at different stocking rates to maintain the quality and quantity of their diet during the grazing season. Journal of Agricultural Science 140: $113-124$.

Goering, H. K., and P. J. Van Soest. 1970. Forage fiber analyses (apparatus, reagents, procedures, and some applications). Washington, DC: Agricultural Research Service-US Department of Agriculture. Agricultural Handbook No. 379. 19 p.

GoRdon, I. J. 1988. Facilitation of red deer grazing by cattle and its impact on red deer performance. Journal of Applied Ecology 25:1-9.

HiratA, M. 1998. Dynamics of the horizontal distribution of herbage mass in a bahiagrass (Paspalum notatum Flügge) pasture grazed by cattle: stability of spatial patterns of herbage mass. Grassland Science 44:169-172.

Illius, A. W. AND I. J. Gordon. 1993. Diet selection in mammalian herbivores: constraints and tactics. In: R. N. Hughes [ED.]. An interdisciplinary approach to foraging behavior. Boston, MA: Blackwell Scientific Publishing. p 157-181.

Illius, A. W., I. J. Gordon, D. A. Elston, and J. D. Milne. 1999. Diet selection in goats: a test of intake-rate maximization. Ecology 80:1008-1018.

Illius, A. W., D. G. M. Wood-Gush, and J. E. Eddison. 1987. A study of the foraging behaviour of cattle grazing patchy swards. Biological Behaviour 12:33-44.

Kenward, M. G., and J. H. Roger. 1997. Small sample inference for fixed effects from restricted maximum likelihood. Biometrics 53:983-997.

Laca, E. A., D. Ungar, N. Seligman, and M. W. Demment. 1992. Effects of sward height and bulk density on bite dimensions of cattle grazing homogeneous swards. Grass and Forage Science 47:91-102.

Lentz, R. D. And G. H. Simonson. 1986. A detailed soils inventory and associated vegetation of Squaw Butte Range Experiment Station. Corvallis, OR: Agricultural Experiment Station, Oregon State University. Special Rep. 760. 184 p.

Lesperance, A. L., V. R. Bohman, and S. W. Marble. 1960. Development of techniques for evaluating grazed forage. Journal of Dairy Science 43:682-689.

Murray, R. B. 1984. Yield, nutrient quality, and palatability to sheep of fourteen grass accessions for potential use on sagebrush-grass range in southeastern Idaho. Journal of Range Management 37:343-348.

[NOAA] National Oceanic and Atmospheric Administration. 2004. Climatological data annual summary, Oregon 42-110:13. Asheville, NC: National Climatic Data Center. $34 \mathrm{p}$.

NoRton, B. E., AND P. S. Johnson. 1986. Impact of grazing on crested wheatgrass in relation to plant size. In: K. Johnson [ED.]. Crested wheatgrass: its values, problems and myths. Symposia proceedings. Logan, UT: Utah State University. p 275-279.

Ogura, S., H. Hasegawa, and M. Hirata. 2002a. Effects of herbage mass and herbage quality on spatially heterogeneous grazing by cattle in a bahia grass (Paspalum notatum) pasture. Tropical Grasslands 36:172-179.

Ogura, S., T. Nakahara, and M. HiRata. 2002b. Spatial distribution of herbage consumption by cattle in a bahiagrass (Paspalum notatum Flügge) pasture monitored two dimensionally. Grassland Science 48:317-325.

Pfeiffer, K. E. And D. C. HaRtnett. 1995. Bison selectivity and grazing response of little bluestem in tallgrass prairie. Journal of Range Management 48:26-31.

Ring, C. B., II, R. A. Nicholson, and J. L. Launchbaugh. 1985. Vegetational traits of patch-grazed rangeland in west-central Kansas. Journal of Range Management 38:51-55.

Robertson, J. B., and P. J. Van Soest. 1981. The detergent system of analyses and its application to human foods. In: W. P. T. James and 0. Theander [EDS.]. The analysis of dietary fiber. New York, NY: Marcell Dekker. p 123-158. 
Romo, J. T., M. E. Tremblay, and D. Barber. 1997. Are there economic benefits of accessing forage in wolf plants of crested wheatgrass? Canadian Journal of Plant Science 77:367-371.

Ruyle, G. B., AND R. W. Rice. 1991. The influence of residual bunchgrass stems on cattle grazing intensity. Abstracts of Annual Meeting Society for Range Management 44:41.

Stuth, J. W. 1991. Foraging behavior. In: R. K. Heitschmidt and J. W. Stuth [eds.]. Grazing management: An ecological perspective. Portland, OR: Timber Press. p 65-83.

Stuth, J. W., J. R. Brown, P. D. Olson, M. R. Araujo, and H. D. Aljoe. 1987. Effects of stocking rate on critical plant-animal interactions in a rotational grazed Schizachyrium-Paspalum savanna. In: F. P. Horn, J. Hodgson, J. J. Mott, and R. N. Brougham [EDS.]. Grazing-lands research at the plant-animal interface. Morrilton, AR: Winrock International. p 115-139.
Ungar, E. D., Z. Henkin, M. Gutman, A. Dolev, A. Genizi, and D. Ganskopp. 2005. Inference of animal activity from GPS collar data on free-ranging cattle. Rangeland Ecology \& Management 58:256-266.

USDA Forest Service. 2006. Burns, Oregon GPS Base station. Available at: http:// www.fs.fed.us/database/gps/burns.htm

Vinton, M. A. and D. C. Hartnett. 1992. Effects of bison grazing on Andropogon gerardii and Panicum virgatum in burned and unburned tallgrass prairie. Oecologia 90:374-382.

Willms, W., A. W. Bailey, A. McLean, and R. Tucker. 1980. The effects of fall grazing or burning bluebunch wheatgrass range on forage selection by deer and cattle in spring. Canadian Journal of Animal Science 60:113-122.

Willms, W. D., J. F. Dormaar, and G. B. SchaalJe. 1988. Stability of grazed patches on rough fescue grasslands. Journal of Range Management 41:503-508. 